\title{
Sospecha de lesión por inhalación y otros factores relacionados con la mortalidad en pacientes quemados hospitalizados en Perú
}

\author{
Suspected inhalation injury and other factors related to mortality in hospitalized burn patients in Peru
}

Suspeita de lesão inalatória e outros fatores relacionados à mortalidade em pacientes queimados hospitalizados no Peru

\section{ARTÍCULO GENERAL}

Kirschbaum Rubin Steven https://orcid.org/0000-00026229-6041

kirschbaumsteven@gmail.com

Universidad Peruana de Ciencias Aplicadas Lima - Perú
Flores Ortega Diego https://orcid.org/0000-00030260-2438

diego.flores.ortega@gmail.com

Universidad Peruana de Ciencias Aplicadas Lima - Perú
Navarro Murgueytio Walter https://orcid.org/0000-00026389-2611 walternavarro30@hotmail.com Hospital Nacional Arzobispo Loayza Lima - Perú
Lucchetti Rodriguez Aldo https://orcid.org/0000-0003-1150$168 \mathrm{X}$

aldolucchetti@gmail.com

Hospital Nacional Arzobispo Loayza Lima - Perú

Recibido 02 de Diciembre 2021 | Arbitrado y aceptado 14 de Marzo 2022 | Publicado en 02 Junio 2022

\section{RESUMEN}

La lesión por inhalación es un factor de riesgo de mortalidad en pacientes quemados; el diagnóstico se sospecha por la historia clínica y los hallazgos. Objetivos: Determinar si la sospecha de lesión por inhalación es un factor de riesgo de mortalidad en pacientes quemados y si existen otros factores de riesgo. Estudio de cohorte retrospectivo que incluyó 156 historias clínicas en la HNAL entre 2015-2016. La variable dependiente fue la mortalidad y las variables independientes incluyeron sospecha de lesión por inhalación, sexo, edad, profundidad y extensión de la quemadura y lugar de origen. Se estimaron los riesgos relativos. Para la recolección de datos se utilizó el "Registro Térmico" HNAL. Análisis descriptivos realizados con mediana, rangos intercuartílicos y frecuencias relativas y absolutas para variables categóricas. En el análisis bivariado se utilizaron las pruebas de Fisher, Chi cuadrado y U de Mann Whitney. La regresión de Poisson se utilizó en el análisis multivariado. Mortalidad global del $9 \%$. El $46 \%$ de los pacientes tenían sospecha de lesión por inhalación. El porcentaje de pacientes fallecidos fue mayor en los expuestos a sospecha de lesión por inhalación $(16,7 \%$ frente a $2,38 \%)$, lugar de origen fuera de Lima $(16,7 \%$ frente a $5,56 \%)$, quemaduras de tercer grado $(13,3 \%$ frente a $1,72 \%)$ y mediana extensión de la quemadura $(56,3$ frente a 10). Sospecha de lesión por inhalación [RR: $6,24 \quad$ (IC95\% 1,48-26,3) (p: 0,013)], quemadura de tercer grado [RR 6,86 (IC95\% 1,1740,2) (p: 0,033)], extensión de la quemadura superior al 11\% [RR 6,12 (IC95\% 1.77-21.1) (p: $0.004)$ y el lugar de origen fuera de Lima [RR 3.69 $(\mathrm{IC} 95 \%$ 1.54-8.86) (p: 0.003)] fueron significativos en el análisis multivariado. Sospecha de lesión por inhalación, quemaduras de tercer grado, extensión mayor al $11 \%$ y lugar de origen fuera de Lima son factores de riesgo de mortalidad en pacientes quemados.

Palabras Clave: Quemaduras, inhalación, accidentes

\section{ABSTRACT}

Inhalation injury is a risk factor for mortality in burn patients; the diagnosis is suspected based on the clinical history and findings. Objectives: To determine if the suspicion of inhalation injury is a risk factor for mortality in burned patients and if there are other risk factors. Retrospective cohort study that included 156 medical records in the HNAL between 2015-2016. The dependent variable was mortality and the independent variables included suspected inhalation injury, sex, age, depth and extent of the burn, and place of origin. Relative risks were estimated. For data collection, the "Thermal Registry" HNAL was used. Descriptive analyzes performed with median, interquartile ranges and relative and absolute frequencies for categorical variables. In the bivariate analysis, the Fisher, Chi square and Mann Whitney U tests were used. Poisson regression was used in multivariate analysis. Overall mortality of $9 \%$. Inhalation injury was suspected in $46 \%$ of the patients. The percentage of deceased patients was higher in those exposed to suspected inhalation injury $(16.7 \%$ vs. $2.38 \%)$, place of origin outside of Lima $(16.7 \%$ vs. $5.56 \%)$, burns of third degree $(13.3 \%$ vs. $1.72 \%)$ and medium extent of the burn (56.3 vs. 10). Suspected inhalation injury [RR: 6.24 (95\% CI 1.48-26.3) (p: 0.013)], third-degree burn [RR 6.86 (95\% CI 1.17-40.2) ( p: 0.033)], burn extension greater than $11 \%$ [RR $6.12(95 \%$ CI 1.77-21.1) (p: 0.004)] and place of origin outside of Lima [RR 3.69 (95\% CI 1.54-8.86) (p: 0.003)] were significant in the multivariate analysis. Suspicion of injury by inhalation, third degree burns, extension greater than $11 \%$ and place of origin outside of Lima are risk factors for mortality in burned patients.

Keywords: Burns, inhalation, accidents

\section{RESUMO}

A lesão inalatória é um fator de risco para mortalidade em pacientes queimados; suspeita-se do diagnóstico com base na história clínica e nos achados. Objetivos: Determinar se a suspeita de lesão inalatória é fator de risco para mortalidade em pacientes queimados e se existem outros fatores de risco. Estudo de coorte retrospectivo que incluiu 156 prontuários no HNAL entre 20152016. A variável dependente foi a mortalidade e as variáveis independentes incluíram suspeita de lesão inalatória, sexo, idade, profundidade e extensão da queimadura e local de origem. Os riscos relativos foram estimados. Para a coleta de dados, foi utilizado o HNAL "Registro Térmico". Análises descritivas realizadas com mediana, intervalos interquartis e frequências relativas absolutas para variáveis categóricas. $\mathrm{Na}$ análise bivariada, foram utilizados os testes de Fisher, Chi quadrado e Mann Whitney U. A regressão de Poisson foi utilizada na análise multivariada. Mortalidade global de $9 \%$. Suspeita-se de lesão inalatória em $46 \%$ dos pacientes. A porcentagem de pacientes falecidos foi maior naqueles expostos a suspeita de lesão inalatória $(16,7 \%$ vs. $2,38 \%)$, local de origem fora de Lima ( $16,7 \%$ vs. $5,56 \%$ ), queimaduras de terceiro grau ( $13,3 \%$ vs. $1,72 \%) \mathrm{e}$ extensão média da queimadura (56,3 vs. 10$)$. Suspeita de lesão por inalação [RR: 6,24 (IC 95\% $1,48-26,3)(\mathrm{p}: 0,013)]$, queimadura de terceiro grau [RR 6,86 (IC 95\% 1,17-40,2) (p: 0,033)], extensão da queimadura maior que $11 \%$ [RR 6,12 (IC 95\% 1,77-21,1) (p: 0,004)] e local de origem fora de Lima [RR 3,69 (IC 95\% 1,54-8,86) (p: 0,003)] foram significativos na análise multivariada. Suspeita de lesão por inalação, queimaduras de terceiro grau, extensão superior a $11 \%$ e local de origem fora de Lima são fatores de risco para mortalidade em pacientes queimados.

Palavras-chave: Queimaduras, inalação, acidentes 


\section{Introduction}

Inhalation injury refers to direct thermal injury of the upper airway, chemical injury of the lower airway or injury by inhalation of fire gases [1]. It has a mortality of $18 \%$ $30 \%$ in burn patients, making it an important risk factor (2-15). Its diagnosis is suspected by thermal exposure in a closed environment and/or clinical signs (dysphonia, wheezing, stridor or carbonic sputum) and confirmed with fibrobronchoscopy $(16,17)$. The aim of this study is to identify the relationship between suspected inhalation injury and mortality in burn patients, as well as other factors involved.

\section{Methodology}

A retrospective cohort study was conducted in a tertiary-level hospital in Lima, Peru during the years 2015-2016, named "Hospital Nacional Arzobispo Loayza" (HNAL), being one of the few reference third-level burn units in the country.

The population of interest for this study were burn patients in the HNAL. The type of sampling was census during the years 2015-2016. Of the total 214 cases, 52 medical records could not be accessed. Of those accessed, hospitalized patients over 18 years of age with a burned body surface area $>1 \%$ were included. Burn patients who died within 24 hours of admission, hospitalized less than 24 hours or with incomplete and inaccurate medical records were not eligible to participate. The Figure 1 shows the flowchart of patients finally chosen for the study.

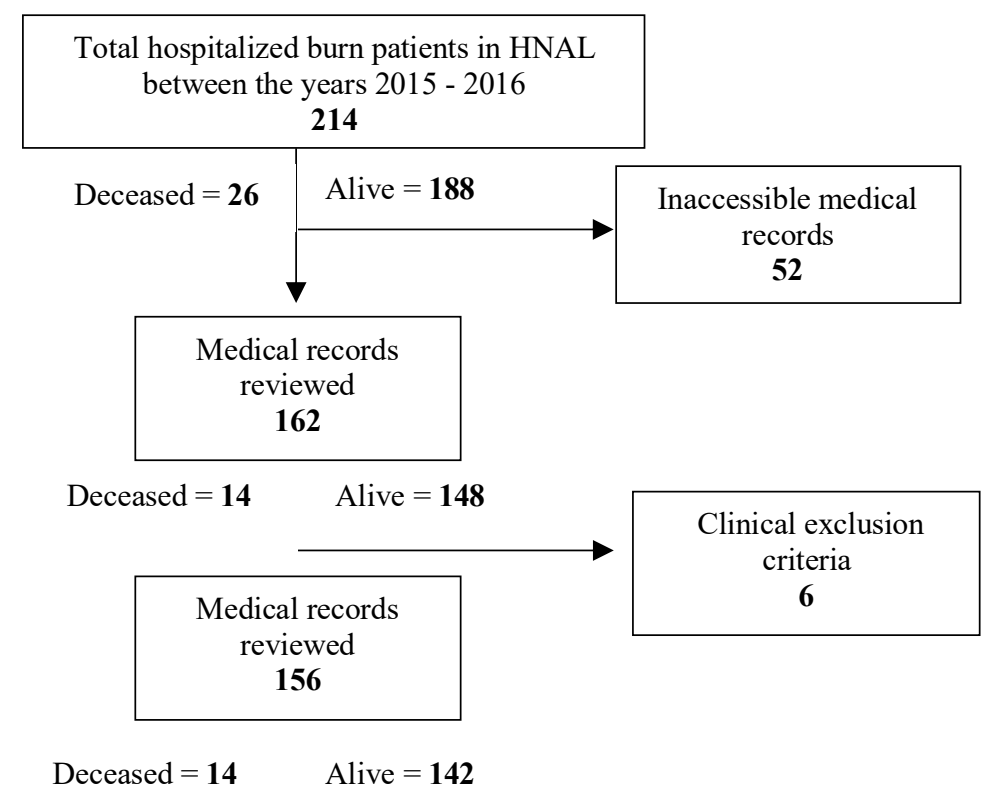

Figure 1: lowchart of patients finally chosen for the study. 
The dependent variable was mortality and the main independent variable was suspected inhalation injury, defined as history of exposure in a closed environment, presence of smoke or loss of consciousness at the accident site, abnormal physical examination with stridor, carbonic sputum, wheezing and/or dyspnea $(16,17)$. Other exposure variables included sex, age, marital status, degree of instruction, occupation, place of origin, burn agent, depth of burn, extension of burn, graft use and admission to the operating room for escharectomy or burn debridement.

The HNAL "Thermic Registry" was used for data recollection. Descriptive analyzes were performed with median and interquartile ranges (IQR) for numerical variables because their distribution was non-normal and relative and absolute frequencies for categorical variables. Fischer, Chi square and U Mann Whitney tests were used in bivariate analysis to evaluate the association between mortality and exposure variables. Statistically significant variables were included in the multivariate model, as well as the variable age, given its biological plausibility $(2,3,6,9)$. Poisson regression was used to estimate relative risks (RR) for the crude and adjusted analysis with $95 \%$ confidence intervals.

Data collection was performed by the researchers, confidentiality was maintained and no patient-related identifiers were used. Given that we did not work with patients, no informed consent was used. The study was presented and approved by the Ethics Committee of the Peruvian University of Applied Sciences (UPC) and HNAL.

\section{Results and Discussion:}

The sociodemographic characteristics of the population are described in table 1. The median age was 41.5 years (RIC 26-54) and 59\% of the participants were male. $31 \%$ of the patients came from departments outside Lima Province.

\section{Table 1}

Sociodemographic characteristics of burn patients in HNAL

\begin{tabular}{|c|c|}
\hline CHARACTERISTICS & VALUES \\
\hline Gender, male (\%) & $92(59.0)$ \\
\hline Age, median (RIC) & $41.5(26-54)$ \\
\hline Civil status (\%) & \\
\hline Single & $52(41.9)$ \\
\hline Married & $68(54.8)$ \\
\hline
\end{tabular}


Kirschbaum R. Steven, Flores-Ortega Diego, Navarro M. W, Lucchetti R. Aldo

\begin{tabular}{|c|c|}
\hline Widowed & $4(3.23)$ \\
\hline Degree of instruction (\%) & \\
\hline Analphabet & $8(9.41)$ \\
\hline Primary level completed & $25(29.4)$ \\
\hline Secondary level completed & $52(61.1)$ \\
\hline Place of origin (\%) & \\
\hline Lima & $108(69.2)$ \\
\hline Others & $48(31.0)$ \\
\hline
\end{tabular}

The clinical characteristics of the population are described in table $1.2 .46 \%$ of burn patients had suspected inhalation injury. The most common burn agent was direct fire (57\%). Likewise, third degree burns (63\%) were the most common and the median extent of burn was $11 \%$ (RIC 6-21.5). The percentage of deceased patients was $9 \%$.

Table 2 compares the characteristics of deceased $(\mathrm{N}=14)$ and alive $(\mathrm{N}=142)$ patients. Deceased patients had a median extent of burn of $56.3 \%$ versus $10 \%$ in alive patients $(\mathrm{p}<0.001$ ). 17\% of patients exposed to suspected inhalation injury died, compared to only $2 \%$ of unexposed patients (p: 0.002 ). In addition, it was found that $17 \%$ of those who came from outside Lima Province died, compared to 6\% who came from Lima Province (p: 0.025). 13\% of patients with third-degree burns died, compared with $2 \%$ with second-degree (p: 0.018 ).

\section{Table 2}

Characteristics of burn patients of HNAL associated with in-hospital mortality

\begin{tabular}{|l|l|l|l|}
\hline & $\begin{array}{l}\text { Deceased N= } \\
\mathbf{1 4}\end{array}$ & Alive N=142 & $\mathbf{P}$ \\
\hline Age, median & $48.5(25-71)$ & $41(26-52)$ & $\mathbf{0 . 2 0 2}$ \\
\hline Sex (\%) & & & 0.199 \\
\hline Female & $8(12.5)$ & $56(87.5)$ & \\
\hline Male & $6(6.52)$ & $86(93.5)$ & \\
\hline Degree of instruction(\%) & & & 0.116 \\
\hline Analphabet & $2(25.0)$ & $6(75.0)$ & \\
\hline Primarylevelcompleted & $1(4.00)$ & $24(96.0)$ & \\
\hline Secondarylevelcompleted & $3(5.77)$ & $49(94.2)$ & \\
\hline Place of origin (\%) & & & 0.025 \\
\hline Lima & $6(5.56)$ & $102(94.4)$ & \\
\hline Others & $8(16.7)$ & $40(83.3)$ & \\
\hline Suspectedinhalationinjury (\%) & & & 0.002 \\
\hline Yes & $12(16.7)$ & $60(83.3)$ & \\
\hline No & $2(2.38)$ & $82(97.6)$ & \\
\hline Burndegree (\%) & & & 0.018 \\
\hline $2^{\mathbf{o}}$ degree & $1(1.72)$ & $57(98.3)$ & \\
\hline $3^{\mathbf{o}}$ degree & $13(13.3)$ & $85(86.7)$ & \\
\hline
\end{tabular}




\begin{tabular}{|l|l|l|l|}
\hline Burnextension, median (RIC) & $56.3(45-85)$ & $10(6-17)$ & $<\mathbf{0 . 0 0 1 *}$ \\
\hline Burnagent (\%) & & & 0.192 \\
\hline Fire & $12(13.5)$ & $53(81.5)$ & \\
\hline Liquid & $2(3.57)$ & $47(95.9)$ & \\
\hline Others & $0(0.00)$ & $11(100.0)$ & \\
\hline$(*)$ Mann-Whitney U stadistical test was used. \\
\hline
\end{tabular}

Table 3 describes our multivariate model, in which suspected inhalation injury had an adjusted RR of 6.24 (95\% CI 1.48-26.3) (p: 0.013), third-degree burn of 6.86 (95\% CI 1.17-40.2) (p: 0.033), extent of burn greater than $11 \%$ of 6.12 (95\% CI 1.77-21.1) (p: 0.004) and place of origin outside Lima Province of 3.69 (95\% CI 1.54-8.86) (p: 0.003), adjusted to the variable age.

Table 3

Crude and adjusted analysis of factors associated with mortality in burn patents fron HNAL during the years 2015-2016 Lima, Perú

\begin{tabular}{|l|l|l|l|l|l|l|}
\hline & $\begin{array}{l}\text { Crude } \\
\text { RR }\end{array}$ & CI 95\% & P & Adjusted RR & CI 95\% & P \\
\hline $\begin{array}{l}\text { Suspected inhalation } \\
\text { injury }\end{array}$ & & & & & & \\
\hline No & 1 & - & - & - & - & - \\
\hline Yes & 7 & $1.61-30.4$ & 0.009 & 6.24 & $1.48-26.3$ & 0.013 \\
\hline 3rd degree burn & & & & & & \\
\hline No & 1 & - & - & - & - & - \\
\hline Yes & 7.69 & $1.03-57.7$ & 0.047 & 6.86 & $1.17-40.2$ & 0.013 \\
\hline Burn extension & & & & & & \\
\hline$<11 \%$ & 1 & - & - & - & - & - \\
\hline$>11 \%$ & 5.85 & $1.35-25.4$ & 0.018 & 7.38 & $1.05-51.7$ & 0.044 \\
\hline Place of origin & & & & & & \\
\hline Lima & 1 & - & - & - & - & - \\
\hline Others & 3 & $1.10-8.20$ & 0.032 & 3.69 & $1.54-8.86$ & 0.003 \\
\hline Age & & & & & & \\
\hline$<41.5$ years & 1 & - & - & - & - & - \\
\hline$>41.5$ years & 1.33 & $0.48-3.68$ & 0.578 & 1.69 & $0.71-$ & 0.237 \\
\hline
\end{tabular}

A total mortality of $9 \%$ was found in burn patients, which falls within the wide range found in the literature, ranging from 2-32\% (6-9, 18-22). Multiple burn studies have been carried out in our country, including the thesis of Zegarra D, et al, which found a mortality of $2 \%$ in a hospital in Arequipa, lower than our finding (19). This difference 
can be explained by multiple factors; $41 \%$ of their burn patients had third degree lesions, while in ours it was $63 \%$; $95 \%$ of their patients came from Arequipa, while $31 \%$ of our population came from departments outside Lima. Likewise, the author Wiegering G, who studied the HNAL burn unit in the years 2010-2013, found a total mortality of $32.1 \%$, considerably higher than ours. This difference can be attributed to the fact that Wiegering G's study had an average extension of $46 \%$, which is greater than ours (11\%). The authors Alp E, et al, conducted a study in a third-level hospital in Turkey, finding a mortality of $7 \%$, similar to ours (9), partially explained by a median extension almost equal to ours, of $12 \%$. Likewise, the authors Kim Y, et al investigated patients in a burn center in Korea, finding a mortality of $25 \%$, which could be attributed to having a high mean extension of $36.8 \%$ (20). Next, the authors Luo G et al, conducted a study of more than 10,000 patients in one of the largest burn centers in the world in Chongqing, China, finding a mortality of $2 \%$, lower than the one found in this study, possibly explained by differences in resources and incidence of inhalation injury, which will be discussed below (22).

This study focused on the suspicion of inhalation injury as a rapid and non-invasive approach compared to fibrobronchoscopy or other auxiliary examinations. There are no standardized criteria for the diagnosis of inhalation injury (22-24). Pedreros P, et al discuss that the most important aspect to diagnose this pathology is clinical suspicion, which is sufficient to carry out an aggressive early management (25). In addition, the International Society for Burn Injuries confirms that signs such as stridor, carbonic sputum, wheezing and dyspnea are strongly suggestive of inhalation injury (17). The use of a clinical diagnosis compared to invasive methods explains why the incidence of inhalation injury is higher in our study (46\%) compared to others, varying between 7 $44 \%(6,7,18,20-22)$. The authors Suzuki M, et al found a $30.4 \%$ incidence in Tokyo, Japan, without considering bronchoscopy mandatory for diagnosis (7). Luo G, et al, found a lower incidence, of $8.01 \%$; possibly explained by different diagnostic criteria and a lower expected burden of patients being a non-specialized center (22). The authors Kim et al report a similar incidence to ours in South Korea, of $43.9 \%$, explaining this high incidence due to being the only third-level burn center in their region (20).

A mortality of $16.7 \%$ was found in patients exposed to inhalation injury, with a RR of 6.24. These results are consistent with those found in the literature, which support inhalation injury as a risk factor for mortality. The authors Cheng $\mathrm{W}$, et al, found a mortality of $24.75 \%$ in patients with inhalation injury with an OR of 6.65 , similar to this 
study (21). Likewise, the authors Suzuki M, et al, found a mortality of 33.6\%, with a RR of 2.58, being the most important predictor of mortality in burn patients in Tokyo (7). The authors Luo G, et al, compared inhalation injury mortality in a decade, finding a decrease of $25.29 \%$ to $11.71 \%$, arguing that this decrease over time is attributed to an early diagnosis, early airway control and use of mechanical ventilation (22).

We found a median extent of burn of $56.3 \%$ in deceased patients and even more, that a burn greater than $11 \%$ of total body surface area increases mortality by 7 times. The authors Lin CC, et al also report a 7-fold increase in mortality in burn patients, but with an extension greater than 20\% (3). The authors You K, et al and Kim Y, et al, found a burn extension similar to ours, of $66 \%$ in deceased patients, significantly greater than in alive patients ( 27 and $33 \%$, respectively) $(8,20)$. On the other hand, the authors Alp E, et al found a lower median extension, of $12 \%$, which also proved to be a mortality risk factor in their multivariate analysis with an OR of 1.05 (9).

In our study, $13.3 \%$ of patients with third-degree burns died, being the highest risk factor for mortality in the multivariate analysis, with a RR of 7.38. These findings agree with the literature, which describes full thickness burns as a risk factor for mortality (7). Likewise, our study found a higher incidence of third degree burn, of $63 \%$, compared to Wiegering G, which was $22.8 \%$ (18).

We found that almost one third of our population came from outside the capital, of which $16.7 \%$ died; moreover, burn patients who came from outside Lima were 3.69 times more likely to die. Different authors have studied the impact of the delay in care until reaching a specialized center. Alp E, et al reported that the risk of mortality was double in patients admitted after 24 hours after the burn (9). Likewise, Wiegering G found a directly proportional relationship between hours elapsed from the burn to hospital admission and mortality (18). Cheng W, et al, found that patients who were admitted 6 hours after the burn had a higher risk of death, with an OR of 1.79 (21). Although we have not studied the number of hours from the burn to hospital admission, it is assumed that patients from departments outside Lima have a longer delay in care than those living in the capital due to the difficult land and air accessibility of our region. It is important to emphasize how crucial the care is in the first hours if inhalation injury is suspected, since upper airway edema peaks in 24 hours and can cause total respiratory obstruction, 
requiring aggressive maneuvers, such as endotracheal intubation or tracheostomy (2629).

Lastly, the variable age was not identified as a significant mortality factor in the bivariate analysis; however, it was included in the multivariate analysis since it is considered a significant predictor of mortality in the literature $(2,3,6,9)$.

There are potential limitations in this study. Being a retrospective study, the information collected from clinical records of the Burn Unit has been developed by different professionals. There were difficulties in completing the total number of recorded charts because many had been lost from the hospital archives. Although we believe it is useful to have the clinical suspicion of inhalation injury, we consider it a limitation not to have equipment or tests to make a confirmatory diagnosis.

Although there are uncontrollable factors that affect the external validity of the study that have been discussed in limitations, this study allows us to make recommendations to improve the management of burn patients, such as updating the protocols regarding the initial evaluation of inhalation injury. In case of suspecting the pathology, we recommend evaluating the degree of upper airway edema and if necessary, proceed to an early airway control. We recommend to opt for a lower cut-off point for burn extension and use it as an alarm criterion to activate an immediate care protocol. The rapid transport of burned patients should be optimized, improving attention at the event site, during transport and admission to the specialized center.

\section{References}

Albright JM, Davis CS, Bird MD, et al. The acute pulmonary inflammatory response to the graded severity of smoke inhalation injury. Crit Care Med. 2012;40:1113

Alp E, Coruh A, Gunay G, Yontar Y, Doganay M. Risk Factors for Nosocomial Infection and Mortality in Burn Patients. J Burn Care Res. 2012 May-Jun;33(3):379-85.

American Burn Association. Guidelines for the operation of burn centers. J Burn Care Res. 2007 Jan-Feb;28(1):79-86.

Burd A. Research in burns - present and future. Indian J Plast Surg. 2010;43(3):11. 
Chen MC, Chen MH, Wen BS, Lee MH, Ma H. The impact of inhalation injury in patients with small and moderate burns. Burns. 2014 Dec;40(8):1481-6.

Cheng W, Shen C, Zhao D, et al. The epidemiology and prognosis of patients with massive burns: A multicenter study of 2483 cases. Burns. 2019 Mar 2. pii: S03054179(18)30694-6.

Cochran A. Inhalation injury and endotracheal intubation. J Burn Care Res. 2009 JanFeb;30(1):190-1.

Dries DJ, Endorf FW. Inhalation injury: epidemiology, pathology, treatment strategies. Scand J Trauma ResuscEmerg Med. 2013 Apr;19;21:31

Foster KN, Holmes JH. Inhalation Injury: State of the Science 2016. J Burn Care Res. 2017 May/Jun;38(3):137-141.

Gupta, K., Mehrotra, M., Kumar, P., Gogia, A.R., Prasad, A., \& Fisher, J.A. (2018). Smoke inhalation injury: Etiopathogenesis, diagnosis, and management. Indian Journal of Critical Care Medicine, 22, 180-188.

Head JM. Inhalation injury in burns. Am J Surg. 1980;139 (4):508-12.

ISBI Practice Guidelines Committee. ISBI Practice Guidelines for Burn Care. Burns 42 (2016) 953-1021.

Kim Y, Kym D, Hur J, et al. Does inhalation injury predict mortality in burns patients or require redefinition?. PLoS One. 2017; 12(9): e0185195.

Lin CC, Liem AA, Wu CK, Wu YF, Yang JY, Feng CH. Severity score for predicting pneumonia in inhalation injury patient. Burns. 2012 Mar;38 (2):203-7.

Luo G, Peng Y, Yuan Z, et al. Inhalation injury in southwest China-The evolution of care. Burns. 2010 Jun;36(4):506-10.

Mlcak R, Buffalo M, Jimenez C. Prehospital Management, Transportation, and Emergency y Care. Total Burn Care. 2018:58-65. 
Mlcak RP, Suman OE, Herndon DN. Respiratory management of inhalation injury. Burns. 2007;33(1):2-13.

Moritz AR, Henriques FC, McLean R. The Effects of Inhaled Heat on the Air Passages and Lungs: An Experimental Investigation. Am J Pathol. 1945 Mar; 21(2): 311331.

Nieman GF, Clark Jr WR, Wax SD, Webb SR. The effect of smoke inhalation on pulmonary surfactant. Ann Surg. 1980;191(2):171-81.

Palmieri TL. Inhalation Injury Consensus Conference: Conclusions. J Burn Care Res. 2009 Jan-Feb;30(1):209-10

Palmieri TL. Inhalation injury: research progress and needs. J Burn Care Res. 2007;28:549-54.

Pedreros P, Longton B, Whittle V, Villegas C. Inhalation injury in burned patient: A review. Rev ChilEnf Respir 2007; 23:117-124.

Shirani KZ, Pruitt Jr BA, Mason Jr AD. The influence of inhalation injury and pneumonia on burn mortality. Ann Surg. 1987;205:82-7.

Suzuki M, Aikawa N, Kobayashi K, Higuchi R. Prognostic implications of inhalation injury in burn patients in Tokyo. Burns. 2005 May;31(3):331-6.

Walker PF, Buehner MF, Wood LA, et al. Diagnosis and management of inhalation injury: an updated review. Crit Care. 2015; 19: 351.

Wanner A, Cutchavaree A. Early recognition of upper airway obstruction following smoke inhalation. Am Rev Respir Dis.1973;108(6):1421-3.

Wiegering G. Factores pronóstico de las complicaciones en el paciente gran quemado. [master's thesis] [Peru]: University of San Martin de Porres; 2015. 75 p.

You K, Yang HT, Kym D, et al. Inhalation injury in burn patients: establishing the link between diagnosis and prognosis. Burns. 2014 Dec;40(8):1470-5. 
Zegarra D, Linares G. Etilogia de las quemaduras y perfil epidemiologico encontrado en pacientes de la unidad de quemados del Hopital Nacional Carlos Alberto Seguin Escobedo. [master's thesis] [Peru]: University of Universidad Católica de Santa María; 2016.100 p. 